\title{
Conditions for monograph projects' by preservice teachers: lessons from the long and winding route
}

Melba Libia Cárdenas B., María Claudia Nieto, and Yudiht Milena Martin

\begin{abstract}
This paper is based on the analysis of the nature of monograph projects undertaken by pre-service teachers at the Universidad Nacional de Colombia. It will examine the main factors that, according to the participants of a case-study, favour or limit the development of those projects. On the basis of our findings, we highlight the conditions associated with the successful fulfilment of what students are required to do in monograph projects.
\end{abstract}

Key Words: pre-service teacher education, formative research, conditions in initial teacher-research preparation

\section{Resumen}

Este documento se basa en el análisis de la naturaleza de los proyectos monográficos desarrollados por los docentes en formación inicial en la Universidad Nacional de Colombia. El informe examina los principales factores que, de acuerdo con los participantes de un estudio de caso, favorecen o limitan el desarrollo de dichos proyectos. Con base en lo encontrado, las autoras destacan las condiciones que se asocian con una culminación exitosa de lo que se exige a los estudiantes en el trabajo de grado.

Palabras Claves: formación inicial de docentes, investigación formativa, condiciones formación inicial de docentes investigadores

* Received: 25-04-05 / Accepted: 15-07-05

1 This paper is based on a project funded by the Research Division of the Universidad Nacional de Colombia in Bogotá (DIB: División de Investigación, Sede Bogotá). Code: 205000. The research group is composed by the authors of this article together with Antje Rüger, Ligia Cortés, and Véronique Bellanger. 


\section{Background}

The participants of our study belong to the three major areas -English, French, and German- which are part of the Philology and Languages programme at the Universidad Nacional de Colombia, Bogotá campus. The study plan is comprised of 8 semesters in which we can find the following main areas: the foreign language component (the target language, civilisation), Spanish and linguistics (semantics, history of language, grammar, phonology, textolinguistics), literature, pedagogy and teaching practice, and research.

The research component is made up of three subjects whose aim is to guide students in the development of their research abilities. The first one, research methodology, is officially included in the fifth semester. It is followed by two monograph seminars that are taken at the end of the university programme according to students' interests. After completion of these courses, students are offered the following three options in order to fulfil the graduation requirements: the writing of a monograph, an internship in an educational institution, or the completion of one semester in a postgraduate programme in the School of Human Sciences.

The students of the Philology and Languages programme belong to low and middle-class strata. They are full-time and day-time students. Most of them come from public education institutions in Bogotá and other cities in the country. It is important to highlight that they rarely come from private bilingual schools. They mostly register in our programme in order to become proficient users of the target languages. The area that embraces the highest number of students is English due mainly to the market demands in areas such as language teaching, language administration, and translation. (Departamento de Lenguas Extranjeras: 2003a).

Just before or upon completion of two-thirds of the major, many of them start working because of their economical and personal situation. This fact makes it difficult for them to carry on with their studies and finish them on time. This problematic and habitual situation made us decide to study in further detail the factors associated with this phenomenon in our language programme.

With respect to the participants of our study, our sample was made up of students and teachers. We gathered information from a group of 42 students, 22 advisors of monograph projects, and 7 teachers of monograph seminars. The first group of participants was composed of students who by the end of 
2000 had finished their study plans (whether or not they had finished their monograph projects) and recently graduated students.

The second group of participants was composed of teachers of monograph seminars and monograph advisors. Most of them were full-time teachers; some were part-time and a few of them were hourly-paid teachers. It should be noted that tutoring students in the development of their monographs was included in their academic duties, except in one case in which an hourly-paid teacher decided to guide some students without seeking remuneration.

\section{Research Problem}

This study focuses on the nature of monograph projects undertaken by undergraduate students. It is an aspect that has worried not only us, but Colombian universities in general. As far as the Universidad Nacional de Colombia is concerned, the monograph project is considered the final product of our students' undergraduate studies and the project in which students apply the knowledge they have acquired in the different subjects and the research skills required to carry out research. An investigation done by Obregón (2001) revealed the main factors that impede the timely graduation of students. Among those we can mention the repetition of subjects, the research project, simultaneous duties (work and study) performed by students, and personal problems.

Taking into account the above situation, as well as concerns from other teachers in the Foreign Language Department and our worries as a research group, we decided to dig into the factors that affect the development of monograph projects and look for real evidence in our university programme which could help solve students' difficulties when writing them. Therefore, we centred our attention on the nature of monograph projects done by Philology and Languages students between 2000 and 2003 to opt for their professional degree.

Our main question stated: What is the nature of monograph projects done by Philology and Languages students between 2000 and 2003 to opt for their professional degree?

In order to account for it, we posed the following sub-questions:

1. What reasons motivate students to decide upon themes for their monograph projects? 
2. What circumstances characterise the development of monograph papers?

3. What is the relationship between the monographs and the professional field?

\section{Research Design}

In order to discover and understand the underlying aspects of phenomena we do not have enough knowledge about -the factors closely related to effective monograph completion- this project followed the principles of a qualitative case study. As pointed out by Merriam (1988), this option helps the researcher focus on groups functioning and to examine data grounded in the context itself; it allows us to study a specific phenomenon and thus, have a detailed and deep examination of the chosen group of participants.

It should be clarified that we started by examining the status of students by paying attention to groups of participants having the following characteristics:

- Students whose monograph projects were in progress and approved.

- Students without an approved project.

- Students who had already finished their projects.

After choosing a group of students from each one of the cases above and making sure we had a diversity of topics in the monograph projects, we contacted them and worked with the ones who expressed their approval and commitment to participate in our project. As far as teachers, we invited all of those who had been in charge of monograph supervision and monograph seminars. We ended up working with the ones who filled the consent form out.

The data collection instruments included, first, the analysis of students' records. Then we gathered information through a survey administered to both students and teachers. It inquired about the topics of students' monograph projects and the reasons for choosing them, the factors associated with the development of their works, their connection to their professional field and their views regarding possible changes in the research component of the undergraduate programme. After the questionnaires were answered, we applied 
semi-structured interviews following the principles of phenomenological interviewing which, according to Siedman (1998), aims at having participants establish the context of their experience within the topic under study to then reconstruct it and examine the meaning it holds for them. This second data collection technique was used in order to validate information provided in the questionnaire, understand the meaning of the research experience for the participants and dig into those aspects that needed further exploration.

The data was analysed following the open coding procedures described by Strauss and Corbin (1990: 61). Generalizations, concepts, or hypotheses emerged from an examination of data -data grounded in the context itself. In tune with the characteristics of qualitative case studies, rather than verifying predetermined hypotheses, the open coding procedures allowed us to cover new relationships, concepts, and understandings.

\section{Theoretical Framework}

Educational research in general and in applied linguistics to TEFL, in particular, have developed significantly in the past few years in our country. The conformation of research groups has sprung up as a result of the interest of the educational community of digging into fields such language acquisition, language teaching and learning, bilingualism, discourse, translation, and teacher education, among others. Likewise, the introduction of the research component in any language programme has become a must. It has become, if not common practice, at least an element to take into account if one is tuned into the realities of the educational processes and willing to explore and improve them. In the context of pre-service education, the component acquires enormous dimensions as future practitioners may become reasonably competent to understand what happens in given settings and to have an impact in the sometimes poor and unfavourable teaching conditions and processes.

Having said so, it is now necessary to shed some light on what research is, specifically in the context of education. Stenhouse (1996) defines it as a systematic and self-critical inquiry. He relates research and teaching by placing emphasis on the role of teachers as they are the ones who live the reality of the classroom and the ones who can really generate changes based on their professional practice. De Tezanos (1998), as Stenhouse, understands research in the frame of daily routines performed both by students and teachers. Within 
this frame pedagogical knowledge is constructed because it gives a context and a sense to teachers' work. On his part, Nunan (1992) defines research as the systematic process of inquiry consisting of the following three elements: (1) a question, problem, or hypothesis; (2) data, and (3) analysis and interpretation of data. These working definitions may help us understand the importance of the teacher as a researcher. It is with this double vision that the teaching practice acquires unlimited dimensions. On the one hand, there is the teacher providing the necessary input and help for students to comprehend, interpret and act upon the knowledge acquired in class. On the other hand, there is the researcher who questions his/her performance, his/her environment, the changes s/he may trigger in order to create or favour conditions that would, in the end, provide better quality in the teaching arena.

It is possible to assert that the research component is a very important element at universities whose aims are directed towards teacher education at the undergraduate level. Universities are conscious of its incorporation in the study plans. The understanding and appropriation of research schemata on the part of students will somehow guarantee a critical position regarding problems that will surely arise in professional life and the search for innovation required to progress, first as individuals, and then as members of a community.

\section{Research in undergraduate programmes in the Colombian context}

In Colombia there is an increasing number of universities that offer undergraduate programmes in the field of teaching foreign languages, English being the one that receives the highest attention. Many of these are accredited by the SNIES (Sistema Nacional de Información de la Educación Superior: The National Information System of Tertiary Education). The emphasis of those programmes varies depending on the target population they want to serve which are preschool, primary or secondary education, basically. According to the Working Document proposed by the Examen de Calidad de Educación Superior ECAES - Tertiary Education Quality Exam- (2004), the research component is explicitly stated as a transverse axe that runs along the programmes.

However explicit the research component may appear along the curricula, it is really crystallised towards the end of the programmes. The ECAES' document (ibid) states that the majority of the programmes restricts the research component to three subjects that could be generalised as research 
techniques I, II, and III. Research is oriented towards the transformation and improvement of pedagogical practices and the topics developed spin around issues such as curriculum, the language discipline itself, pedagogy and the human side of teaching.

The inclusion of the research component in pre-service education somehow demonstrates an interest in providing an academic profile that will equip professionals in the teaching of foreign languages with critical thinking and tools to excel in their professional practice. Certainly the research component provides some of the basis. It is through observation and reflection that students start to wonder about the current state of affairs. The curricular structuring of the foreign language programmes in the country, however, does not foster this directly from the research component as it is introduced late in the programmes.

Research is seen as an axle that joins together the various components of the curriculum and thus is an experience that enables student-teachers to develop a productive professional life. The results obtained will benefit the community the teachers belong to. On the other hand, the research component will set the bases for further studies that will surely demand a working knowledge to create new possibilities in the educational field or recreate existing ones, all of them with the intention of searching for better teaching conditions and widening teachers' knowledge base.

\section{Findings:}

\section{Monograph writing: A long and winding route}

In order to analyse the information obtained from surveys and interviews coming from the participants, as a research team, we decided on a metaphor that would help us make sense of the data. The metaphor selected was a journey. In order to start a journey, it is necessary to have clear different aspects such as: purpose of the trip, destination, itinerary, tickets, provisions, and alternative plans in case of need. Every journey also provides lessons for future destinations. The visualisation of these elements is possible if we imagine a journey divided by legs or portions: Getting ready for the adventure, The journey, and Lessons for future adventures.

\section{Getting ready for the adventure}


In the context of our analysis the research component in the curriculum of the programme of Philology and Languages at the Universidad Nacional de Colombia was understood as that journey every student is to take towards the end of his/her permanence at the university in order to fulfill the requirements for graduation. The Getting ready for the adventure leg consists of those preparatory courses and experiences that expectantly pave the way for him/her to go smoothly along the route. The quality of this preparatory stage varies depending on factors such as the preparation of the teachers who are going to be tutors in the different seminars and certain future advisors; the solid bases in the understanding of the nature of research possible in the educational field; the timely definition of a sound research question; the understanding and possible appropriation of research instruments; and a working knowledge on data analysis together with acceptable writing and argumentative skills.

The journey leg comprises the trip itself in which the student faces the many positive or negative situations that can arise in an adventure of this nature. Among the positive aspects it is possible to mention how motivated $\mathrm{s} / \mathrm{he}$ is regarding the topic selected for the research project, the companions from whom $\mathrm{s} /$ he can derive many lessons, the benefits of team work coming from the advisor, the juror or his/her colleague -if s/he is doing the project with someone else-, the community being affected with the research study, and the connection with a reality the student must be prepared to face in his/her professional life. The experience gained from this part of the journey seems to be very enriching as it provides the foundations for an attitude for life regarding the changes we can effect in an environment provided we understand our roles and the elements we can have influence on.

However, this portion of the trip cannot be that easygoing as the student realises that there are many impediments to her/his arriving at the final destination as scheduled. Maybe the most troublesome areas include the low level s/he has in his/her argumentative and writing skills; the lack or low theoretical preparation to deal with the area of interest and with the research process itself; the problems arising from external factors such as the impossibility to have an advisor assigned to his/her proposed topic of research on time; the long time taken by some jurors to deliver a concept on the monograph project; the sometimes unknown criteria on which his/her work is going to be measured; the span of time between the initiation of the trip and the estimated time of arrival; and his/her very own personal circumstances that can force him/her to suddenly change the itinerary or even come to a halt. 
The Lessons for future adventures leg occurs at the moment the student arrives at his/her final destination, in our case, the oral defense of the monograph project. It is a spark of reflection and confrontation with the self. This momentum permits the traveler to consider aspects s/he may not have thought about at the beginning because of lack of information, preparation, interest, motivation, or guidance. His/her reflections on this topic constitute important pieces of advice for future travelers including the students, advisors, jurors, and the administrative staff of the university.

As can be felt from the discussion regarding the journey and its portions, it is vital then to act upon the factors that are susceptible to change. The following section will show the conditions we consider important to maintain or create in order to really pave the road for pre-service teachers in their initial preparation in the research field.

\section{Some conditions for effective monograph achievements: A means to pave the road}

As already said, students belonging to languages pre-service programmes are expected to fulfill a requirement in the area of research. In order to arrive at this goal, they are provided with initiating conditions that will enable them to understand and carry out the research process. Some students end up being more prepared than others. This may depend on many factors such as the philosophy of the programmes students are registered in, the number of hours allocated for such end, teacher preparation, and university infrastructure, among many.

Along the process of data analysis, we have noticed that our participants' experiences, concerns and views in connection to the requirements needed to effectively complete monographs in a reasonable period of time have allowed us to define a series of conditions required to overcome common difficulties and to provide the lead for the successful ending of a route that often turns out to be thorny. To begin with, it should be clarified that, in this context, conditions are understood as statements that describe what students should know or be able to achieve in their monographs as well as the elements or tools the university should provide to ensure monograph completion in a reasonable period of time. Conditions, in this context, should also define how work is to be done in order to establish clarity and agreement among students, monograph supervisors, 
jurors, and the academic bodies who are responsible for the application of administrative regulations. This coincides with the following participant who points out that "We have to work in more detail in the definition of standards to ensure the quality of monographs" (T21, survey). The definition of standards might be the next step to follow once we consider the conditions participants feel should be provided to achieve their goals. For the time being, we will concentrate on the given requirements.

Conditions for effective monograph achievement should be, on the one hand, the circumstances under which the monograph is to be assembled; on the other, the manner in which the work is to be performed. In the following paragraphs we present the main conditions we pulled together after analysing the data we gathered through questionnaires and interviews. They emerge as commonly felt needs or suggestions pointed out by both students and teachers for a more pleasant journey. The voices of participants, whose identity is protected by using $\mathrm{T}$ for teacher and $\mathrm{S}$ for student, will be heard along the next section as a means to illustrate some of the issues being discussed.
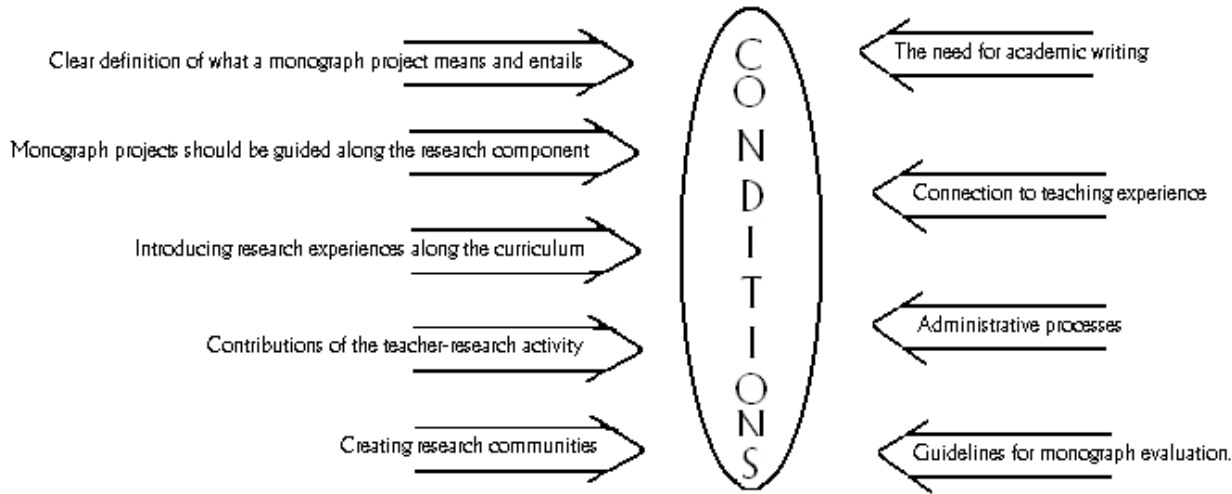

Diagram 2. Conditions for successful monograph completion

\section{Clear definition of what a monograph project means and entails}

Universities should be clear about the results expected from undergraduate students when engaging in monograph projects. A monograph is understood as a written document based on research around a specific theme, which 
presents the ideas in an organised and systematic way. In our particular context, monographs are seen as research exercises. Therefore, and given the fact that for most students the monograph is the first research attempt, they are recommended to opt for a well-organized reflective exercise with a practical application rather than for a big discovery or scientific development (Comité Asesor Carrera de Filología e Idiomas: 2003). This is stressed by one of the partcipants who asserts that "The interesting thing of an investigation is that it should have a real influence on people's life" (S8, 181-182, interview).

As can be seen, instead of discouraging students to investigate, they are being made conscious of the fact that in the undergraduate programme they should get the basis to then undertake postgraduate programmes which prioritise the research component.

\section{Monograph projects should be guided along the research component}

In section 1 we explained that our undergraduate students are expected to examine research issues in three subjects: research methodology and two monograph seminars. It is also expected that the last two courses illuminate them to begin the monograph work. However, oftentimes we find cases in which students do the last two courses to just fulfil a requirement. It is then necessary that universities make the research courses more meaningful and focused so as to ensure students can link their contents to a concrete project. This linkage can be attained if students have an aim defined in a specific project under the guide of the research component teachers.

\section{Introducing research experiences along the curriculum}

Although the monograph is expected to be an opportunity for students to take advantage of input provided along the major, this is not the general rule. The tendency to provide students the necessary knowledge base often leaves the research activity to the searching of relevant literature and to the writing of essays. As noted by a teacher, "Students do not have previous research experience and it is evident that the papers they present at the end of a term are not useful examples to follow because they do not require starting from a hypothesis, but developing a theme assigned by the teacher." (T6, survey). 
Although the academic exercises mentioned above are important practices to then face the challenge of writing a monograph, most participants stress the need of engaging students in small-scale projects. For examples,

"... as an undergraduate student I think that to start doing a monograph, it would be great doing small research papers that would prepare us to do the real monograph." (S13, interview 222-225)

"Perhaps we should do more monographs along our major (...) The last one would be something like the summary or a compilation, another exercise. We wouldn't mystify it as much as we do now. Completing the monograph is scary, awful..." (T20, interview 275-280)

We can see that for successful monograph completion, prior research experiences are vital to provide the necessary tools. Likewise, and as can be read in the second testimony above, the monograph could be divided into several exercises as a means to help students overcome fears and misconceptions they often have about the final project.

In the same vein, two different participants note how important it is to be more in tune with process-oriented methodologies, to wit:

"From my experience, the monograph is a research requirement with no clear preparation along the major. It does not correspond to the culmination of a process." (T6, survey).

"Investigating is a process knowledge, it is like learning to skate. If you try the skates before the race, surely you won't fall before you reach the end... In this case, if you do research before the final monograph, surely you will do it faster. Besides, if teachers have defined research areas in which they involve students before the monograph, the skating-rink will be more even..." (S26, survey).

We could confirm that if the teachers in charge of monograph seminars have got experience in doing research and use that experience as a working tool to illustrate the processes students should bear in mind, there is a positive impact on their progress. "The teacher was doing an investigation and... she shared her findings with us or what she was discovering or the analysed data. Thus, it was very motivating..." (S13, interview 154-158).

The last two excerpts show that the pedagogical processes of the research courses shape the way students acquire research knowledge. We can observe 
that, as proposed by Sánchez and Jurado (2001), research as an activity that generates knowledge is an essential element in initial teacher preparation and an exercise to foster projects that contribute to professional preparation. It would also be very interesting to analyse how the research component is introduced to students during the first semesters, what the role of teachers is in the understanding and application of research methodologies, and how motivating they are for their students to undertake the research route as a process and not as an end product.

\section{Contributions of the teacher-research activity}

Some testimonies presented so far illustrate that many students go through college without getting research experience. This might make us realise that we often forget that by doing research, we get so much more out of our classes and what is said or addressed in class is much more concrete. This also leads us to consider how practical research courses are and how much students can gain if we engage them in the development of our projects or use what we are experiencing while doing research to guide them or illustrate theoretical aspects.

\section{Creating research communities}

Another important aspect is to create teacher research communities which could produce strong research lines and, at the same time, involve teachers in research projects that provide them with experience and expertise in their advisor's role. Additionally, they will acquire tools for developing sound monograph seminars to offer students. The obvious result will be the bettering of their teaching practice and the improvement of research itself, which will permit them to articulate what is done and produced in the seminars and what students will finally do in their projects. With strong research lines, students will be informed about the research areas in which they can develop their graduation proposals, will develop clearer objectives for their work, and will take a shorter period of time carrying them out.

\section{The need for academic writing}

According to $38.09 \%$ of the advisors we surveyed, students often lack solid academic bases and this makes it difficult to develop the project. Lack of sufficient conceptual bases and writing competences force advisors to 
bridge the gap. "I didn't know that the tutorials had to be remedial work." (T19, survey). This excerpt evidences that the deficiencies many students bring from secondary school often remain. Thus, and as stressed by another teacher, we need to give more attention to the argumentative skills students should continue developing as soon as they begin their tertiary education. To quote one teacher, "Writing -I insist- is a practical work, a continuous work from the first semesters." (T10, interview, 64-66).

\section{Monographs concerning education or pedagogy should be ideally con- nected to teaching experiences}

In order of frequency, the students we surveyed opted for themes in the areas of pedagogy, translation, linguistics, and literature. Those interested in pedagogy did so with the purpose of innovating in a given context and, thus, chose themes concerning curricular proposals, materials design, exploration of teaching practices, and to a lesser extent, teacher education. Teaching is the area most students like to inquire about and acknowledge the many possibilities it has to investigate. This is confirmed by one of the participants who, when asked why he chose the theme for the monograph, said: "Because I like teaching and I thought there was a wide field to investigate." (S31, survey).

In view of students' growing interest in investigating in the educational field, we consider that monographs concerning education or pedagogy should be ideally connected to experiences students live in that field. This could be fostered by incorporating more practical activities in the English language teaching methodology courses and in the teaching practice so that students make connections between areas of interest and their potential for research projects. Besides, those experiences could be exploited more in depth as to allow students to collect and monitor the experience with the researcher lens other than the student-teacher one.

\section{Administrative processes}

Another point worth discussing is how agile administrative processes are in our undergraduate programs. In order to make the graduation process easier, we can design and apply clear standards and guidelines which can be used by all participants involved in this process (teachers, students, and administrative staff). In these guidelines we can specify, among other factors, 
the possible topics to be researched, the advisor's role, the student's role, and the graduation requirements.

\section{Guidelines for monograph evaluation.}

Getting feedback from evaluators or readers who have not been involved in the development of our work has several benefits, to wit: we can enrich it by seeing aspects one might have ignored or not properly addressed; we can validate to what extent what we write makes sense to others; and we can also get familiarized with the idea of being evaluated -a common but feared practice in the academic arena. Nonetheless, the fact that very often our participants mentioned lack of clear criteria for monograph evaluation made us think about the importance of having precise guidelines to assess final reports. As noted by one of the teachers we interviewed, we need parameters to determine if it is "a worthy peace or work, well-written, with good use of references, with achieved goals, with conclusions beyond data analysis so that they (students) make inferences..." (T19, interview, 27-30)

Thus, and on the basis of our experiences as students, teachers of research seminars, jurors of monograph reports and/or advisors, we designed a checklist (see appendix 1) which was piloted with students engaged in classroom research projects. As can be seen in the document, the proposed evaluation criteria are grouped around two main areas, which are, the sections of the report and its scientific rigor.

\section{Conclusions}

According to our findings we can infer some critical points which need improvement for making students' research projects an effective and efficient process. These fundamental points are related to the administrative processes involved in the acquisition of the undergraduate degree, lack of sufficient teacher research groups, and lack of theoretical foundation required from students for them to assume a more confident role as researchers.

We have also pointed out the need for a higher number of research opportunities and practice for students. For overcoming this problem, it is necessary to prepare them from the very beginning of the major in research activities, such as mini research projects, which will guide them throughout 
the whole undergraduate programme. This way, the negative feelings common among students undergoing these processes will perhaps be avoided.

Conceptions of knowledge about research are both personal and contextually-based. However, and given the fact that research is one of the pillars of initital teacher preparation, we dare say that the conditions discussed in this paper might be of interest to other universities facing similar problems.

The conduct of research means care, honesty, rigor, time, and patience with our methods of data collection and analysis, our interpretations and our language. In view of this, we have stressed the need for providing students with more research opportunities and practices from the very beginning of the undergraduate programme. We also know that being a good researcher involves more than just coming up with brilliant ideas and implementing them. Doing research implies spending the majority of our time reading papers, discussing ideas with colleagues, writing and revising papers, staring blankly into space -and, of course, having brilliant ideas and implementing them. All of this could be enhanced by having more projects involving teachers and students so that we broaden academic communities and enlighten their work through the interplay of its various members. In doing so, rather than emphasizing teaching over research (or vice versa), we would strive for teaching through research.

University administrative processes have an impact on successful completion of studies as well as on effective use of resources. Universities are concerned about the amount of time students take to graduate, but they should also revise how agile administrative processes are, such as assigning advisors and jurors, having clear guidelines for administrative processes to complete so that they can finally graduate, defining research areas, and guiding students on possible topics to investigate, among others. In addition, clear benchmarks to measure student academic achievement need to be defined in the light of both international requirements and our national contexts. These, we are sure, are critical aspects for students to keep track of where they are going with their research, to stay motivated, and to know how to use their time wisely. 


\section{References}

Comité Asesor Carrera de Filología e Idiomas. Departamento de Lenguas Extranjeras. (2003a). Lineamientos para la realización de los trabajos de grado en la Carrera de Filología e ldiomas. Universidad Nacional de Colombia: Bogotá.

Departamento de Lenguas Extranjeras. (2003a). Auto evaluación del programa curricular Filología e Idiomas: Universidad Nacional de Colombia: Bogotá.

De Tezanos, A. (1998). Aproximaciones metodológicas para la enseñanza del enfoque cualitativo-interpretativo en la investigación social. In Una Etnografía de la Etnografía. Santafé de Bogotá: Antropos, Colección Pedagogía Siglo XXI.

ICFES-Instituto Colombiano para el Fomento de la Educación Superior. (2004). Examen de Calidad de Educación Superior ECAES. Bogotá: ICFES.

Merriam, S. B. (1988). Case Study Research in Education: A Qualitative Approach. San Francisco: Jossey-Bass.

Nunan, D. (1992). Research Methods in Language Learning. Cambridge: Cambridge University Press.

Obregón, D. (2001). Revisión de los requisitos de grado: El trabajo de grado. Universidad Nacional de Colombia: Bogotá.

Sánchez, V. and Jurado, F. (2001). La Práctica como Motor de la Transformación de la Formación Docente (Inicial y Continua). In La formación docente en América Latina. Bogotá: Universidad Nacional de Colombia, Programa Universitario de Investigación en Educación: Evaluación Censal de Competencias Básicas - Cooperativa Editorial Magisterio.

Siedman, I. (1998). Interviewing as Qualitative Research. New Cork: Teachers College Press.

Stenhouse, L. (1996). La investigación como base de la enseñanza. Madrid: Morata.

Strauss, A. and Corbin, J. (1990). Basis of Qualitative Research. Grounded Theory Procedures and Techniques. Newbury Park: Sage Publications. 


\section{Appendix 1: evaluation format for monographs}

Universidad Nacional de Colombia

Department of Foreign Languages

Philology and Languages Programmes

Student's name:

Code: Major:

Title of paper:

Evaluator's name:

Role of the evaluator:

Director

Second evaluator

Date of evaluation:

The conventions for evaluating the document are:

$E=$ excellent, $G=$ Good, $A=$ Acceptable, $D=$ Deficient.

Based on the evaluation, the score is assigned as follows:

1. Content and formal aspects:

2. Pertinence, scientific rigor and conclusions: maxim 15 points

maxim 35 points

Total: maxim 50 points

\section{Formal aspects: components of the paper}

\begin{tabular}{|l|l|l|}
\hline & Yes & No \\
\hline Covers & & \\
\hline Table of contents & & \\
\hline Introduction with a justification & & \\
\hline Conceptual, referential, or theoretical framework & & \\
\hline $\begin{array}{l}\text { Formulation of research question/ hypothesis/ objectives -according to the type of graduation option } \\
\text { selected by student }\end{array}$ & & \\
\hline Methodological design & & \\
\hline Results / data analysis & & \\
\hline Conclusions & & \\
\hline Bibliography & & \\
\hline Relevant annexes & & \\
\hline Norms of presentation (ICONTEC, number of words, and/or other university dispositions) & \\
\hline Others: (specify) & & \\
\hline Comments: & Score for the first part: & \\
\hline$\quad$ (maxim 15 points). \\
\hline
\end{tabular}




\section{Scientific rigor}

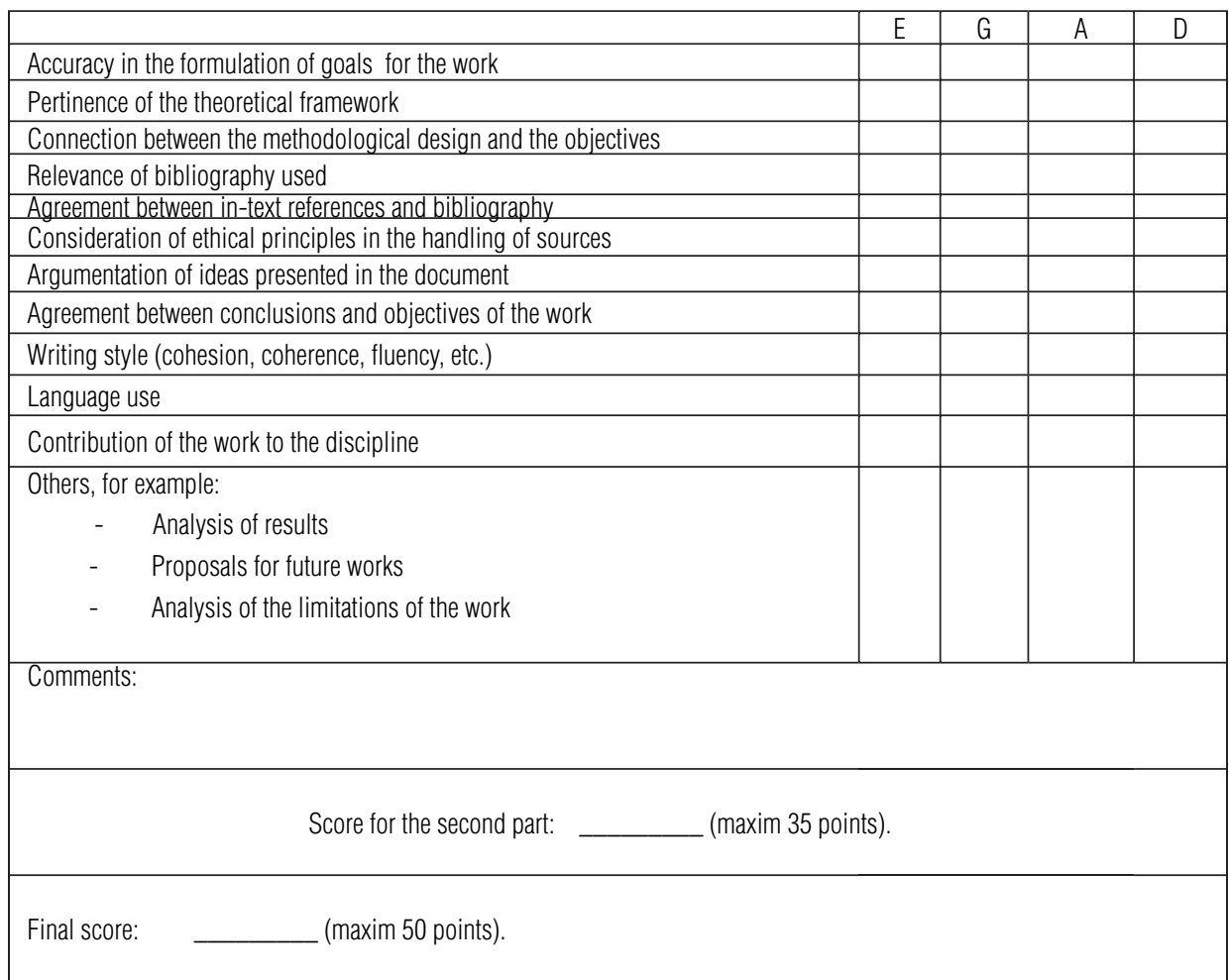

The final grade for the monograph is

(Evaluator's signature)

This format was proposed by Professors Ligia Cortés, María Claudia Nieto, Véronique Bellanger, Melba Libia Cárdenas, Antje Rüger, as part of the research project "Case-study: Monograph projects by preservice teachers of the Philology and Languages Programme (English, French, German) at the Universidad Nacional de Colombia from 2000 to 2003: Analysis and perspectives", 2005. With the collaboration of Yudiht Martín (research assistant) and students from the Monograph Seminars of German II and Classroom Research II, first semester 2004. 


\section{THE AUTHORS}

Melba Libia Cárdenas, MA in TESOL from The University of Edinburgh, is an associate professor at Universidad Nacional. She is the coordinator of the research group PROFILE recognised by Colciencias and of the inservice programmes for teachers of English. She is also a lecturer of the Masters in Applied Linguistics to TEFL at Universidad Distrital and of the Graduate Programme in Bilingual Education at Universidad El Bosque.

\section{E-mail: mlcardenasb@unal.edu.co}

Maria Claudia Nieto, MA in ESP from University of Warwick, has developed her professional profile in ESP, English for general purposes, and pre and in-service education. She is an assistant professor at Universidad Nacional de Colombia and member of the PROFILE research group.

\section{E-mail:mcnietoc@unal.edu.co}

Yudiht Martin, holds a B. Ed in Philology and Languages from Universidad Nacional de Colombia. She has taught ESP courses at UN-ALEX Programme, UN-Extension Programmes and has also worked as a research assistant of the PROFILE research group.

\section{E-mail: ymmartinc@,unal.edu.co}

